novel field of research was being made deliberately. The popular nightmare, that genetic manipulators might, even by accident, create especially virulent microorganisms, was never more than a scare: if that were possible in the laboratory, evolution would surely long since have found a way. For a time, however, it was proper that people should be concerned at the movement of oncogenes from one genome to another, or about the possibility that infection with artificial organisms might create immunological problems. With the passage of time, it has become clear that these risks, always hypothetical, are even more remote than they might have been. Now the regulatory committees have become rubber stamps for research proposals in whose assessment laboratory investigators are usually more skilled than most committee members. Many of these proposals are in any case covered by other kinds of legislation. Thus the production of genetically engineered organisms on a commercial scale falls within the scope of legislation on occupational health, work with microorganisms whose natural virulence is a serious threat to human health is covered by legislation of the kind that protects the health of laboratory pathologists and the like, while plant and animal pathogens fall within the scope of regulations designed for the protection of agriculture.

So why not simply abolish the committees, and the requirement that investigators should solicit even post hoc approval for proposed experiments? The only justification for keeping this apparatus in being that the public is still disquieted about the potential of genetic manipulation. Can this be so, as the daily newspapers retail how products made by genetic manipulation one day a sweetening agent, the next a lymphokine - trickle onto the market? The existence of committees such as GMAG in Britain and the Recombinant DNA Advisory Committee (RAC) in the United States has contributed invaluably to this mood. The result is that such residual public anxiety as persists is centred not on questions of safety but, in a loose sense, on what might be called ethics. Under what safeguards and by what criteria will physicians in due course embark on gene therapy - still a somewhat distant prospect (see Nature 298,$416 ; 1982$ ) in spite of some injudicious experiments based on starkly different assumptions. But surely the best safeguard of the public interest against the abuse of clinical techniques is that hospital ethical committees should be effective, and publicly recognized to be so.

All this argues for disbanding both the committees and the procedures that sustain them - a logic that governments seem unwilling to accept. The British Government's preferred solution, that its advisory committee should give advice to the quasi-independent body called the Health and Safety Executive, chiefly concerned with occupational health, is sensible enough: if some part of the government machine senses the need for advice on any subject, that must surely be a sign of grace. But the proposal that the notification procedure should continue as at present, although no longer onerous, is in the circumstances unnecessary, even pointless, and should be dropped.

The President's commission (which was an independent body and which has acted like that) also comes out for some continuing committee but for different reasons. Starting with the proposition that the federal government must have a continuing responsibility not merely for the safety and ethical practice of genetic manipulation but for the promotion of the new technology that follows therefrom, it recommends a standing commission to tackle problems as they arise, giving advice to anyone prepared to listen. Such a commission, if it had the clout, could rid the field of the adversarial politics with which it has been plagued in the past decade. But otherwise the device would be of little value. It is hard to see how a single committee, however well provided with resources, could anticipate and then resolve all the questions, which are certain to arise in this rapidly evolving technology. Modestly, the President's commission says that the proposed standing commission called the "third-generation RAC" should not be a continuation of itself. But it overlooks the dangers in singling out one field of science and technology for special treatment in such a way, and also the present federal government's distaste for new committees.

\section{Licence for cooperation}

\section{May's economic summit may provide a licence}

for technical collaboration. High time.

Prosperous governments are all alike (and a little smug); every unprosperous government is unprosperous in its own way (and at the same time convinced that it is being done down by others). This is the spirit in which heads of government usually assemble for the meetings now called economic summits which have become a regular feature of Western diplomatic life. But the next such meeting, due to take place next month at Williamsburg, Virginia, will have the benefit of at least one potentially significant emollient of this sense that everybody is at odds with everybody else - the report of the working group on "Technology, growth and employment" commissioned by last year's summit at Versailles and now published (see Nature 31 March, p.365). This document should be a reminder to political leaders preoccupied with what they hope is the fag-end of the long recession that the future prosperity of the states they represent will depend critically on their willingness in concert to nurture the technical basis of their domestic economies.

The origins of this document are interesting in themselves, stemming from the case made at Versailles a year ago by the President of France that technology must be an important part of economic introspection. The working party, consisting mostly of chief scientific advisers to governments, has accepted the Mitterrand view that science and technology are the only engines of future prosperity in sight, has deftly devised a set of definitions of the role of governments as sponsors of innovation in the mixed economies of the industrialized West and has made a plea (accompanied by some specific suggestions) for more collaboration between the summit governments on a variety of basic research projects. Artfully, no doubt, the working party has calculated that its document, which is constructive while giving no offence but which is unlikely to be a central part of the agenda, will be politely blessed at Williamsburg in terms that provide officials with responsibility for the administration of research and development with a licence to do what they can.

Not before time. While most of the summit governments pay frequent lip-service to the principle that there should be more international collaboration on basic research, and many of them already collaborate on various projects (CERN, for example, or the Large Space Telescope), they are unreasonably shy of putting their money where their mouths are if there is a hint that collaboration might bring commercial benefits to others than themselves. What else can explain most governments' unwillingness to share the huge cost of carrying fast reactors from the prototype stage to reality - a cause that has been urged on them for at least the past quarter of a century? Why not even go further, as is now suggested, and collaborate on the development of robots, or in biotechnology? For even when the field concerned may yield products that may be commercially exploited in the short term, provided that the rules of commercial competition are agreed - and kept - no collaborator would be left with a sense of having been cheated. To the extent that collaboration is a means of making fuller use of what skill there is, the game is not a zerosum game.

Even if the Williamsburg summit accepts this proposition only on the nod, we shall all be winners. Even the fear that the more effective use of technical resources by the industrialized nations of the West will further widen the gulf between them and the developing nations may be misplaced, for effective innovation provides the best hope that industrialized states will cease protecting dying industries against competition from developing countries. And if Williamsburg goes according to this plan, there may be a few crumbs for the academic research community if only because everybody now appreciates that even the United States cannot support all the projects, in planetary science for example, that make sense. The summit is unlikely to pledge money for this good course, Italy's and France's wishes apart. But the licence will be sufficient. 